\title{
Tumor Necrosis Factor Receptor Superfamily Member 6B
}

National Cancer Institute

\section{Source}

National Cancer Institute. Tumor Necrosis Factor Receptor Superfamily Member 6B. NCI

Thesaurus. Code C30112.

Tumor necrosis factor receptor superfamily member 6B (300 aa, $33 \mathrm{kDa}$ ) is encoded by the human TNFRSF6B gene. This protein plays a role in the inhibition of apoptosis. 